\title{
Implementasi Algoritma Naive Bayes Untuk Menentukan Lokasi Strategis Dalam Membuka Usaha Menengah Ke Bawah di Kota Medan (Studi Kasus: Disperindag Kota Medan)
}

\author{
Samuel Suprianto \\ Program Studi Teknik Informatika, STMIK Budi Darma, Medan, Indonesia \\ Email: samuelsuprianto105@gmail.com
}

\begin{abstract}
Abstrak-Usaha dapat di pengaruhi dari letak lokasi dan jenis usaha apa yang dibangun di lokasi yang ditentukan dan dapat berkembang seiring berjalannya waktu tetapi tidak sedikit kemungkinan terjadinya gulung tikar dikarenakan jenis usaha tersebut tidak berada pada lokasi yang tepat dan menjanjikan dikarenakan adanya faktor-faktor yang tidak mendukung pada lokasi tersebut, termasuklah itu wilayah tersebut yang jumlah penduduk tidak terlalu padat dan lahan yang tidak begitu luas. Untuk itu penulis melakukan penelitian mengenai lokasi yang strategis untuk membuka suatu jenis usaha tertentu tergantung pada lokasi yang ditemukan dengan metode Naive Bayes. Dimana metode tersebut digunakan untuk memprediksi secara tepat dari sekian banyaknya lokasi yang telah di riset setelah itu ditentukanlah mana yang lebih tepat daerahnya.
\end{abstract}

Kata Kunci: Lokasi Strategis, Data Mining, Naive Bayes

Abstract-The business can be influenced by the location of the location and the type of business that was built in the specified location and can develop over time but it is not impossible for bankruptcy to occur because the type of business is not in the right location and promising due to factors that do not support at that location, include that area where the population is not too dense and the land is not that large. For this reason, the authors conduct research on strategic locations to open a particular type of business depending on the location found by the Naive Bayes method. Where the method is used to predict accurately from the many locations that have been researched after that it is determined which is more appropriate area.

Keywords: Strategic Location, Data Mining, Naive Bayes

\section{PENDAHULUAN}

Dinas Perindustrian dan Perdagangan Kota Medan atau di singkat DISPERINDAG Kota Medan sebagai instansi untuk mengeluarkan surat izin usaha yang akan di bangun pengusaha tersebut, begitu juga sebagai instansi yang dapat membuat kesepakatan kerja sama antara pengusaha dan DISPERINDAG untuk membangun usaha yang akan dilakukan sesuai dengan lokasi yang sudah ditentukan.

Kendala yang terjadi di dalam menentukan lokasi di dirikannya suatu usaha yaitu dikarenakan lokasi yang tidak berada pada ruang lingkup masyarakat umum begitu juga dengan jenis usaha yang tidak diminati masyarakat, lokasi yang tidak strategis dapat menimbulkan dampak pada jenis usaha yang akan dibangun sehingga tidak sedikit pula adanya kemungkinan terjadinya kebangkrutan serta menimbulkan kerugian dan kegagalan dalam kerja sama yang sudah di sepakati[1].

Jenis usaha apa yang akan dijalankan, dapat disimpulkan bahwa banyak daerah di wilayah kota medan yang harus dilakukan riset lokasi untuk menentukan letak strategis dalam menjangkau masyarakat dan mempermudah masyarakat untuk mendapatkan kebutuhan yang mereka inginkan. Sehingga tidak memerlukan waktu yang lama ke tempat tujuan lokasi usaha yang diperlukan konsumen. Data ini diperlukan untuk mengetahui atau mendapatkan lokasi yang tepat untuk melakukan proses dalam menentukan tujuan atau strategi maka data tersebut akan dikelompokkan ke dalam kriteria data pengelompokan lokasi yang strategis menggunakan Algoritma Naive Bayes[2].

\section{METODE PENELITIAN}

\subsection{Data Mining}

Data mining adalah proses yang mempekerjakan satu atau lebih teknik pembelajaran komputer (machine learning) untuk menganalisis dan mengintegrasi suatu pengetahuan (knowladge) secara otomatis. Knowladge Discovery in database $(K D D)$ adalah penerapan metode saintik pada data mining. Dalam konteks ini data mining merupakan satu langkah dari proses KDD[3].

\subsection{Algoritma Naïve Bayes}

Naive Bayes merupakan pengklasifikasian dengan metode probabilitas dan statistik yang dikemukakan oleh ilmuan Inggris Thomas Bayes, merupakan teknik prediks berbasis probabilistik sederhana yang berdasarkan pada penerapan teorema Bayes (atau aturan Bayes) dengan asumsi independensi (ketidaktergantungan) yang kuat (Naif). Dengan kata lain, dalam Naive bayes, model yang digunakan adalah "model fitur independen". Dalam Bayes (terutama Naive Bayes), maksud independensi yang kuat pada fitur adalah bahwa sebuah fitur pada sebuah data tidak berkaitan dengan ada atau tidaknya fitur lain dalam data yang sama. 
Prediksi Bayes didasarkan pada teorema Bayes dengan formula umum [2]. Sebagai berikut :

$P(H \mid X)=\frac{P(X \mid H) \cdot P(H)}{P(X)}$

Keterangan:

$\mathrm{X} \quad$ : Data dengan class yang belum diketahui

$\mathrm{H} \quad$ : Hipotesis data merupakan suatu class spesifik

$\mathrm{P}(\mathrm{H} \mid \mathrm{X}) \quad$ : Probabilitas hipotesis berdasar kondisi (posteriori probability)

$\mathrm{P}(\mathrm{H}) \quad$ : Probabilitas hipotesis (priori probability)

$\mathrm{P}(\mathrm{X} \mid \mathrm{H}) \quad$ : Probabilitas berdasarkan kondisi pada Data Sampel

$\mathrm{P}(\mathrm{X}) \quad$ : Probabilitas X

Adapun kelebihan dan kekurangan algoritma Naive Bayes [2]. Dapat di uraikan sebagai berikut:

1. Kelebihan Naive Bayes :

a. Mudah di implementasikan.

b. Hasil baik dalam banyak kasus.

2. Kekurangan Naive Bayes :

a. Tidak berlaku jika probabilitas kondisionalnya adalah nol, apabila nol maka probabilitas prediksi akan bernilai nol juga.

b. Mengasumsikan variabel bebas.

\section{HASIL DAN PEMBAHASAN}

Kendala yang terjadi di dalam menentukan lokasi didirikannya suatu usaha yaitu dikarenakan lokasi yang tidak berada pada ruang lingkup masyarakat umum begitu juga dengan jenis usaha yang tidak diminati masyarakat, lokasi yang tidak strategis dapat menimbulkan dampak pada jenis usaha yang akan dibangun sehingga tidak sedikit pula adanya kemungkinan terjadinya kebangkrutan serta menimbulkan kerugian dan kegagalan dalam kerja sama yang sudah di sepakati.

Selama ini cara yang dilakukan maupun kerja sama yang dihasilkan belum maksimal, dikarenakan belum lengkapnya semua data lokasi yang ada. Begitu juga pada saat ingin mendapatkan surat izin usaha, dapat dikeluarkan dengan terlebih dahulu dilakukan peninjauan lokasi dimana dapat di ambil keputusan yang mampu dipahami dan diketahui jenis usaha seperti apa nantinya yang akan dijalankan. Dimana pengesahan tidak lagi langsung pada pemimpin DISPERINDAG tetapi bisa melalui wakilnya atau seketaris yang berada di kantor maupun pada saat berada di lokasi.

Jenis usaha apa yang akan dijalankan, dapat disimpulkan bahwa banyak daerah di wilayah kota medan yang harus dilakukan riset lokasi untuk menentukan letak strategis dalam menjangkau masyarakat dan mempermudah masyarakat untuk mendapatkan kebutuhan yang mereka inginkan. Sehingga tidak memerlukan waktu yang lama ke tempat tujuan lokasi usaha yang diperlukan konsumen. Data ini diperlukan untuk mengetahui atau mendapatkan lokasi yang tepat untuk melakukan proses dalam menentukan tujuan atau strategi maka data tersebut akan dikelompokkan ke dalam kriteria data pengelompokan lokasi yang strategis menggunakan Algoritma Naive Bayes.

Data ini dapat diolah kemudian suatu saat akan diperlukan dalam melakukan suatu tujuan penting untuk menentukan lokasi-lokasi yang strategis di wilayah Kota Medan. Kategori-kategori yang sudah didapatkan akan diolah dengan menggunakan algoritma Naive Bayes untuk menentukan peluang prediksi lokasi yang tepat berdasarkan DISPERINDAG Kota Medan, 2018.

Tabel 1. Data lokasi di Kota Medan

\begin{tabular}{|c|c|c|c|c|c|c|c|c|c|}
\hline No & $\begin{array}{c}\text { Wilayah Kota } \\
\text { Medan }\end{array}$ & $\begin{array}{c}\text { Minat } \\
\text { Masyarakat }\end{array}$ & $\begin{array}{c}\text { Jarak } \\
\text { Jangkauan } \\
\text { Masyarakat } \\
\end{array}$ & $\begin{array}{c}\text { Volume } \\
\text { Kendaraan }\end{array}$ & $\begin{array}{c}\text { Kebersihan(Lingkungan } \\
\text { bersih yang jauh dari lokasi } \\
\text { pembuangan sampah) }\end{array}$ & $\begin{array}{l}\text { Keamanan } \\
\text { yang } \\
\text { Terjamin } \\
\end{array}$ & $\begin{array}{c}\text { Kelengkapan } \\
\text { Usaha }\end{array}$ & Lahan & Keterangan \\
\hline 1 & $\begin{array}{l}\text { Kec. } \\
\text { Medan Are }\end{array}$ & Sedang & Jauh & Rendah & Sedang & Aman & $\begin{array}{l}\text { Kurang } \\
\text { Lengkap }\end{array}$ & $\begin{array}{l}\text { Tidak } \\
\text { Luas }\end{array}$ & Tidak \\
\hline 2 & $\begin{array}{l}\text { Kec. } \\
\text { Medan } \\
\text { Barat }\end{array}$ & Tinggi & Jauh & Rendah & Bersih & $\begin{array}{l}\text { Tidak } \\
\text { Aman }\end{array}$ & Lengkap & Luas & Strategi \\
\hline 3 & $\begin{array}{l}\text { Kec. } \\
\text { Medan } \\
\text { Baru }\end{array}$ & Sedang & Jauh & Rendah & Sedang & Aman & $\begin{array}{l}\text { Kurang } \\
\text { Lengkap }\end{array}$ & $\begin{array}{l}\text { Tidak } \\
\text { Luas }\end{array}$ & Tidak \\
\hline 4 & $\begin{array}{l}\text { Kec. } \\
\text { Medan } \\
\text { Belawan } \\
\text { Kota }\end{array}$ & Tinggi & Dekat & Tinggi & Sedang & $\begin{array}{l}\text { Tidak } \\
\text { Aman }\end{array}$ & Lengkap & $\begin{array}{l}\text { Tidak } \\
\text { Luas }\end{array}$ & Strategi \\
\hline 5 & $\begin{array}{l}\text { Kec. } \\
\text { Medan Deli }\end{array}$ & Tinggi & Dekat & Tinggi & Bersih & $\begin{array}{l}\text { Tidak } \\
\text { Aman }\end{array}$ & Lengkap & $\begin{array}{l}\text { Tidak } \\
\text { Luas }\end{array}$ & Strategi \\
\hline 6 & $\begin{array}{l}\text { Kec. } \\
\text { Medan } \\
\text { Denai }\end{array}$ & Sedang & Dekat & Rendah & Bersih & $\begin{array}{l}\text { Tidak } \\
\text { Aman }\end{array}$ & Lengkap & $\begin{array}{l}\text { Tidak } \\
\text { Luas }\end{array}$ & Tidak \\
\hline
\end{tabular}


DOI 10.30865/json.v1i2.1939

\begin{tabular}{|c|c|c|c|c|c|c|c|c|c|}
\hline 7 & $\begin{array}{l}\text { Kec. } \\
\text { Medan } \\
\text { Helvitia }\end{array}$ & Sedang & Jauh & Rendah & Bersih & Aman & Lengkap & Luas & Tidak \\
\hline 8 & $\begin{array}{l}\text { Kec. } \\
\text { Medan } \\
\text { Johor }\end{array}$ & Tinggi & Dekat & Tinggi & Sedang & Aman & $\begin{array}{l}\text { Kurang } \\
\text { Lengkap }\end{array}$ & Luas & Strategi \\
\hline 9 & $\begin{array}{l}\text { Kec. } \\
\text { Medan } \\
\text { Kota }\end{array}$ & Tinggi & Dekat & Tinggi & Sedang & Aman & Lengkap & Luas & Tidak \\
\hline 11 & $\begin{array}{l}\text { Kec. } \\
\text { Medan } \\
\text { Maimun }\end{array}$ & Sedang & Dekat & Tinggi & Bersih & $\begin{array}{l}\text { Tidak } \\
\text { Aman }\end{array}$ & $\begin{array}{l}\text { Kurang } \\
\text { Lengkap }\end{array}$ & $\begin{array}{l}\text { Tidak } \\
\text { Luas }\end{array}$ & Strategi \\
\hline 12 & $\begin{array}{l}\text { Kec. } \\
\text { Medan } \\
\text { Marelan }\end{array}$ & Sedang & Jauh & Tinggi & Bersih & Aman & $\begin{array}{l}\text { Kurang } \\
\text { Lengkap }\end{array}$ & Luas & Strategi \\
\hline 14 & $\begin{array}{l}\text { Kec. } \\
\text { Medan } \\
\text { Petisah }\end{array}$ & Tinggi & Dekat & Rendah & Bersih & $\begin{array}{l}\text { Tidak } \\
\text { Aman }\end{array}$ & $\begin{array}{l}\text { Kurang } \\
\text { Lengkap }\end{array}$ & Luas & Tidak \\
\hline 15 & $\begin{array}{l}\text { Kec. } \\
\text { Medan } \\
\text { Polonia }\end{array}$ & Sedang & Dekat & Tinggi & Sedang & $\begin{array}{l}\text { Tidak } \\
\text { Aman }\end{array}$ & $\begin{array}{l}\text { Kurang } \\
\text { Lengkap }\end{array}$ & Luas & Tidak \\
\hline 16 & $\begin{array}{l}\text { Kec. } \\
\text { Medan } \\
\text { Selayang }\end{array}$ & Sedang & Jauh & Rendah & Sedang & $\begin{array}{l}\text { Tidak } \\
\text { Aman }\end{array}$ & Lengkap & $\begin{array}{l}\text { Tidak } \\
\text { Luas }\end{array}$ & Strategi \\
\hline 17 & $\begin{array}{l}\text { Kec. } \\
\text { Medan } \\
\text { Sunggal }\end{array}$ & Sedang & Jauh & Rendah & Sedang & $\begin{array}{l}\text { Tidak } \\
\text { Aman }\end{array}$ & Lengkap & $\begin{array}{l}\text { Tidak } \\
\text { Luas }\end{array}$ & Strategi \\
\hline 20 & $\begin{array}{l}\text { Kec. } \\
\text { Medan } \\
\text { Tuntungan }\end{array}$ & Tinggi & Jauh & Tinggi & Sedang & Aman & Lengkap & $\begin{array}{l}\text { Tidak } \\
\text { Luas }\end{array}$ & Strategi \\
\hline
\end{tabular}

Adapun alur dari metode Naive Bayes adalah sebagai berikut :

1. Mulai

2. Baca data training

a. Hitung $\mathrm{P}(\mathrm{Ci})$ untuk setiap kelas

b. Hitung $\mathrm{P}(\mathrm{X} \mid \mathrm{Ci})$ untuk setiap kriteria dan setiap kelas

c. Cari $\mathrm{P}(\mathrm{X} \mid)$ yang paling besar menjadi kesimpulan

3. Tampilkan hasil prediksi.

Adapun dari hasil smua data yang sudah di kmpulkan terdapat 7 kriteria yang harus di miliki setiap usaha yang akan dibangun, yaitu terdiri dari beberapa kriteria sebagai berikut:

1. Minat masyarakat

Tabel 2. Minat masyarakat

\begin{tabular}{ccccc}
\hline \multirow{2}{*}{ Minat masyarakat } & \multicolumn{4}{c}{ Keterangan } \\
\cline { 2 - 5 } & Strategis & Tidak strategis & $\mathrm{P}($ strategis $)$ & P(tidak strategis) \\
\hline Tinggi & 6 & 4 & 0,6 & 0,4 \\
Sedang & 4 & 6 & 0,4 & 0,6 \\
Total & 10 & 10 & & \\
\hline
\end{tabular}

2. Jarak jangkauan masyarakat

Tabel 3. jarak jangkauan masyarakat

\begin{tabular}{ccccc}
\hline \multirow{2}{*}{ Jarak jangkauan masyarakat } & \multicolumn{4}{c}{ Keterangan } \\
\cline { 2 - 5 } & Strategis & Tidak strategis & $\mathrm{P}($ strategis $)$ & $\mathrm{P}($ tidak strategis $)$ \\
\hline Dekat & 4 & 6 & 0,4 & 0,6 \\
Jauh & 6 & 4 & 0,6 & 0,4 \\
Total & 10 & 10 & & \\
\hline
\end{tabular}


3. Volume Kendaraan

Tabel 4. Volume kendaraan

\begin{tabular}{ccccc}
\hline \multirow{2}{*}{ Volume kendaraan } & \multicolumn{4}{c}{ Keterangan } \\
\cline { 2 - 5 } & Strategis & Tidak strategis & $\mathrm{P}($ strategis $)$ & $\mathrm{P}($ tidak strategis $)$ \\
\hline Tinggi & 5 & 5 & 0,5 & 0,5 \\
Rendah & 5 & 5 & 0,5 & 0,5 \\
Total & 10 & 10 & & \\
\hline
\end{tabular}

4. Kebersihan (Lingkungan yang bersih, jauh dari lokasi pembuangan sampah)

Tabel 5. Kebersihan

\begin{tabular}{ccccc}
\hline \multirow{2}{*}{ Kebersihan Ligkungan } & \multicolumn{4}{c}{ Keterangan } \\
\cline { 2 - 5 } & Strategis & Tidak strategis & P(strategis) & P(tidak strategis) \\
\hline Bersih & 5 & 5 & 0,5 & 0,5 \\
Sedang & 5 & 5 & 0,5 & 0,5 \\
Total & 10 & 10 & & \\
\hline
\end{tabular}

5. Keamanan yang terjamin

Tabel 6. Keamanan

\begin{tabular}{ccccc}
\hline Keamanan yang & \multicolumn{4}{c}{ Keterangan } \\
\cline { 2 - 5 } terjamin & Strategis & Tidak strategis & P(strategis) & P(tidak strategis) \\
\hline Aman & 6 & 4 & 0,6 & 0,4 \\
Tidak aman & 4 & 6 & 0,4 & 0,6 \\
Total & 10 & 10 & & \\
\hline
\end{tabular}

6. Kelengkapan usaha (seperti air, dan listrik)

Tabel 7. Kelengkapan usaha

\begin{tabular}{ccccc}
\hline Kelengkapan usaha (seperti air, & \multicolumn{4}{c}{ Keterangan } \\
\cline { 2 - 5 } dan listrik) & Strategis & Tidak strategis & P(strategis) & P(tidak strategis) \\
\hline Lengkap & 6 & 4 & 0,6 & 0,4 \\
Tidak lengkap & 4 & 6 & 0,4 & 0,6 \\
Total & 10 & 10 & & \\
\hline
\end{tabular}

7. Lahan (toko, dan parkiran)

Tabel 8. Lahan

\begin{tabular}{ccccc}
\hline \multirow{2}{*}{ Lahan (toko, dan parkiran) } & \multicolumn{4}{c}{ Keterangan } \\
\cline { 2 - 5 } & Strategis & Tidak strategis & P(strategis) & P(tidak strategis) \\
\hline Luas & 4 & 6 & 0,4 & 0,6 \\
Tidak luas & 6 & 4 & 0,6 & 0,4 \\
Total & 10 & 10 & & \\
\hline
\end{tabular}

Dimana data uji 1 : diambil dari data no 1-20

berikut ini akan di urutkan kebenaran strategisnya melalui perhitungan algoritma Naive Bayes menggunakan rumus :

$P P(H \mid X)=\frac{P(X \mid H) \cdot P(H)}{P(X)} P(X \mid H) X \frac{P(H)}{P(X)}$

Maka hasilnya dapat di bentuk kedalam tabel class yang terdapat di Kota Medan untuk menentukan tabel nomor 1 sampai dengan nomor 20, letak lokasi yang strategis dari ke 20 lokasi tersebut dapat di lihat pada tabel di bawah ini sebagai berikut :

Tabel 9. Hasil lokasi strategis

\begin{tabular}{|c|c|c|c|c|c|c|c|c|c|}
\hline No & $\begin{array}{c}\text { Wilayah Kota } \\
\text { Medan }\end{array}$ & $\begin{array}{c}\text { Minat } \\
\text { Masyarakat }\end{array}$ & $\begin{array}{c}\text { Jarak } \\
\text { Jangkauan } \\
\text { Masyarakat }\end{array}$ & $\begin{array}{l}\text { Volume } \\
\text { Kendaraan }\end{array}$ & $\begin{array}{c}\text { Kebersihan(Lingkungan } \\
\text { bersih yang jauh dari lokasi } \\
\text { pembuangan sampah) }\end{array}$ & $\begin{array}{c}\text { Keamanan } \\
\text { yang } \\
\text { Terjamin }\end{array}$ & $\begin{array}{c}\text { Kelengkapan } \\
\text { Usaha }\end{array}$ & Lahan & Keterangan \\
\hline 2 & $\begin{array}{l}\text { Kec. } \\
\text { Medan } \\
\text { Barat }\end{array}$ & Tinggi & Jauh & Rendah & Bersih & $\begin{array}{l}\text { Tidak } \\
\text { Aman }\end{array}$ & Lengkap & Luas & Strategi \\
\hline 4 & $\begin{array}{l}\text { Kec. } \\
\text { Medan }\end{array}$ & Tinggi & Dekat & Tinggi & Sedang & $\begin{array}{l}\text { Tidak } \\
\text { Aman }\end{array}$ & Lengkap & $\begin{array}{l}\text { Tidak } \\
\text { Luas }\end{array}$ & Strategi \\
\hline
\end{tabular}




\begin{tabular}{|c|c|c|c|c|c|c|c|c|c|}
\hline & $\begin{array}{l}\text { Belawan } \\
\text { Kota }\end{array}$ & & & & & & & & \\
\hline 7 & $\begin{array}{l}\text { Kec. } \\
\text { Medan } \\
\text { Helvitia }\end{array}$ & Sedang & Jauh & Rendah & Bersih & Aman & Lengkap & Luas & Tidak \\
\hline 13 & $\begin{array}{l}\text { Kec. } \\
\text { Medan } \\
\text { Perjuangan }\end{array}$ & Tinggi & Dekat & Tinggi & Sedang & Aman & Lengkap & $\begin{array}{l}\text { Tidak } \\
\text { Luas }\end{array}$ & Tidak \\
\hline 16 & $\begin{array}{l}\text { Kec. } \\
\text { Medan } \\
\text { Selayang }\end{array}$ & Sedang & Jauh & Rendah & Sedang & $\begin{array}{l}\text { Tidak } \\
\text { Aman }\end{array}$ & Lengkap & $\begin{array}{l}\text { Tidak } \\
\text { Luas }\end{array}$ & Strategi \\
\hline 17 & $\begin{array}{l}\text { Kec. } \\
\text { Medan } \\
\text { Sunggal }\end{array}$ & Sedang & Jauh & Rendah & Sedang & $\begin{array}{l}\text { Tidak } \\
\text { Aman }\end{array}$ & Lengkap & $\begin{array}{l}\text { Tidak } \\
\text { Luas }\end{array}$ & Strategi \\
\hline 20 & $\begin{array}{l}\text { Kec. } \\
\text { Medan } \\
\text { Tuntungan }\end{array}$ & Tinggi & Jauh & Tinggi & Sedang & Aman & Lengkap & $\begin{array}{l}\text { Tidak } \\
\text { Luas }\end{array}$ & Strategi \\
\hline
\end{tabular}

Dari hasil data lokasi yang sudah di dapat disimpulkan bahwa wilayah yang terpilih menjadi lokasi strategis untuk membuka usaha kuliner terdiri dari beberapa kecamatan yang berada di Kota Medan dengan kriteria yang beragam.

\subsection{Implementasi}

Implementasi sistem program ini mencakup spesifikasi kebutuhan perangkat keras (hardware) dan spesifikasi perangkat lunak (software). Hasil pengujian pada Penerapan Data Mining untuk pengelompokkan Data Lokasi di Kota Medan dengan menggunakan algoritma Naive Bayes, berikut klasifikasinya setiap atribut.

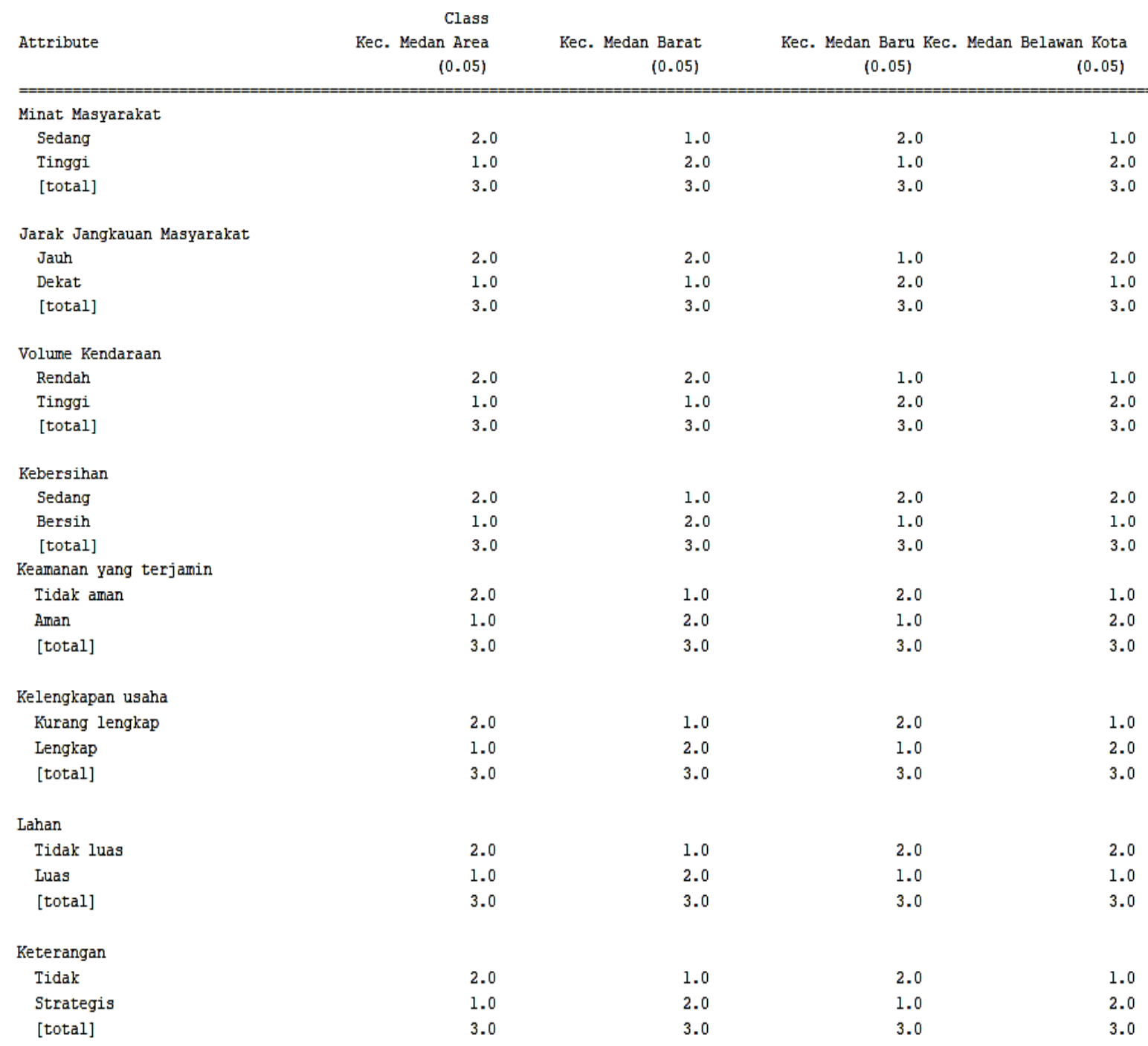

Gambar 1. Hasil klasifikasi Aplikasi Weka

Dari hasil klasifikasi yang dibuat oleh aplikasi weka, seluruh data atribut dapat diklasifikasikan dengan baik. 


\section{KESIMPULAN}

Berdasarkan implementasi dan pengujian pada Penerapan Data Mining untuk pengelompokkan Data Lokasi di Kota Medan dengan menggunakan algoritma Naive Bayes, dan Dari data hasil klasifikasi yang telah dilakukan di pembahasan sebelumnya, maka dapat dibuat beberapa lokasi yang ada di Kota Medan yang dapat dilakukan oleh pihak DISPERINDAG dan Pengusaha agar lokasi yang strategis di kecamatan Kota Medan lebih efektif dan efisien, adalah sebagai berikut :

1. Berdasarkan pengetahuan dari hasil penyelesaian algoritma Naive Bayes menentukan lokasi berdasarkan usaha apa yang akan di bangun pada Kecamatan yang ada di Kota Medan

2. Proses hasil lokasi yang ditentukan mampu menunjang dan mendongkrak peluang bisnis yang menjanjikan agar dapat berkembang serta bersaing di bidang usaha

3. Klasifikasi atau pengelompokan data yang digunakan oleh algoritma Naive Bayes pada data lokasi dapat dikelompokkan dengan baik sesuai dengan kriteria-kriteria yang telah di tentukan sebelumnya dan Jika data yang digunakan lebih banyak maka proses perhitungan akan lebih sulit dan akan membutuhkan waktu yang cukup lama.

\section{REFERENCES}

[1] Pearce II, John A., dan Robinson, Richard B. 2011. Strategic Management : Formulation, Implementation and Control, Twelfth Edition New York : Mc Graw Hill

[2] Alfa Saleh. Implementasi Metode Klasifikasi Naive Bayes dalam Memprediksi Besarnya Penggunaan Listrik Rumah Tangga. Citec Journal, 2010, 2 (3), 209.

[3] Kusrini dan Emha Taufiq Luthfi, 2009. Algoritma Data Mining, Andi Offse

[4] Usman, Nurdin. (2002). Konteks Implementasi Berbasis Kurikulum. Jakarta:PT. Raja Grafindo Persada.

[5] Tan, P. Et al.2006. Introduction to data Mining. Boston: Pearson Education.

[6] Ridwan, M., Suyono, H., Sarosa, M., 2013, Penerapan Data Mining untuk Evaluasi Kinerja Akademik Mahasiswa Menggunakan Algoritma Naive Bayes Classifier, Jurnal EECCIS, Vol 1, No. 7, Hal. 59-64.

[7] Seminar Nasional Teknologi Informasi \& Komunikasi Terapan 2012 (Semantik 2012) Semarang 23 Juni 2012

[8] Bramer dan Max, 2007. Principles of Data Mining. Springer Science

[9] Capello, Roberto. 2011. Location, Regional Growth and Local Development Theories. Dipartimento BESTPolitecnico di MilanoPiazza Leonardo da Vinci 3220133. Giugno.

[10] Miles, Mike E. Et al. 1999. Real Estate Development, Principles and Process. Washington DC: Urban Land Institute.

[11] Jogiyanto, H.M, 2005, Analisis dan Desain Sistem Informasi, Andi Offset, Yogyakarta.

[12] Bonnie Soeherman dan Marion Pinontoan. 2008. Designing Information System.Yogyakarta. Elex Media Komputindo.

[13] Krismiaji, 2010. Sistem Informasi Akuntansi. Yogyakarta: UPP AMP YKPN

[14] Rumbaugh, J., Jacobson, I., \& Booch, G. 2005. The Unified Modeling Language Reference Manual Second Edition. Canada: Pearson Education.

[15] Rosa.a.s; M. Shalahuddin, 2016. Rekayasa Perangkat Lunak (Terstruktur dan Berorientasi Objek), INFORMATIKA. Bandung, BIObses, Hal. 137-238.

[16] Dimov, Rossen, 2007. WEKA : Praktical machine learning tools and techniques with java implementations. AI Tools Seminar.

[17] Bouckaert, Remco R.; Frank, Eibe; dkk. 2008. WEKA Manual for Version 3-6-0. New Zealand: University of Waikato

[18] Hariyanto, Bambang, Sistem Manajemen Basis Data: Pemodelan, Perancangan, dan Terapannya, Informatika, Bandung: 2004.

[19] Jarot S., Shenia A., Sudarma S., Buku Pintar Mocrosoft Office 2007 \& 2010 Word-Excel-PowerPoint, Media Kita, 2012 